\title{
Moving Beyond Tradition: Technologies Facilitating Students' Cognitive Ability and Modifying Pedagogical Practices of School
}

\author{
Librarians in Jamaica and Antigua
}

\begin{abstract}
School library collections in Jamaica and Antigua have moved beyond the traditional print-only collection to various technologies that facilitate teaching and learning. Some of these technologies are not directly located in the library but are placed in computer labs where the school librarians have access to them. This research was conducted to determine what types of technologies were used in the libraries studied, how they facilitated students' cognitive skills, and how they modified school librarians' pedagogical practices. The sample consisted of 52 school librarians in Jamaica and Antigua. The findings showed that participants had or had access to technologies such as multimedia projectors, interactive SMART Boards, computers with and without internet access, and tablets. These technologies facilitated students' cognitive behavior by providing them with additional content, and promoted active learning, among other things. Participants' pedagogical practices were modified as they now deliver instruction using PowerPoint, blogs, Twitter, Facebook, podcasts, and e-books.
\end{abstract}

Keywords: Cognitive ability and technology, technologies in school libraries, pedagogy and technology, school libraries in Jamaica and Antigua

\section{Introduction}

Prior to the era of electronic technology, school libraries were institutions that concentrated on the acquisition of knowledge intended to be shared for the development of the society (Bonanno, 2012). However, in the $21^{\text {st }}$ century, school libraries have become hi-tech learning centers designed to prepare students for responsible citizenship and enable them to function effectively in a complex information landscape (Hay \& Todd, as cited in Bonanno, 2012). Robinson (as cited in Peltier-Davis \& Rennick, 2007, p. 99) mentioned that in the Caribbean, Jamaica and Antigua were among the few countries with a semblance of school library services. Her research indicated that historically, in Jamaica, school libraries were predominantly print-based, with less than $20 \%$ having common multi-media formats such as CD-ROMs, audio cassettes, and video-tapes ( $p$. 104). The same can be said of the school libraries in Antigua.

Over time, computers were introduced in these school libraries, which were basically used for word processing because of these schools' lack of internet connection. In recent times, more and more schools have obtained internet connection and a number of supporting technologies. This change supports the use of technologies by this generation of secondary school students who are described as "born digital," that is, born between 1996 and the present. They see digital technology as the norm, as it has been fully integrated into their lives (Green \& Hannon, as cited in Klopfer, Osterweil, Groff, \&Haas, 2009, p. 5).

\section{Purpose and significance of the study}

The purpose of thisstudy is to ascertain the technological infrastructure of secondary school libraries in Jamaica and Antigua and to determine how these technologies have facilitated the cognitive ability of students and modified the pedagogical practices of these schools' librarians. 
Providing information technology tools in school libraries is highly valued since this digital-born generation has gravitated toward them. Therefore, this study will provide evidence-based results on how various technologies facilitate students' cognitive ability. The researchers hope to consequently impress the Ministries of Education in Jamaica and Antigua with the need to provide more technologies in school libraries to improve students' academic performance. Students' learning outcomes are heavily dependent on the pedagogical strategies used by teachers because the methodology and instructional materials they use can contribute to students' academic performance. If the findings indicate that the use of technology by school librarians hasindeed improved their pedagogical practices, the Ministries of Education in Jamaica and Antigua could use the findings to substantiate placing more technologies in school libraries to support teaching and learning.

\section{Theoretical framework underlying cognition and technology}

Cognitive Consultant International Limited postulates that "as technologies advance, they are quickly penetrating more into the daily life of ordinary people as well as into human expert domains. As technologies are used in our cognitive processes, as they cognitize with us and for us, they influence and impact the very way we acquire information and think, and affect the very nature of cognition. Such technologies can be characterised and termed as Cognitive Technologies" (para.1). The writer further explains that training and education are now using and integrating the World Wide Web, podcasts, mobile and distance learning, interactive videos, serious games, and a whole range of e-learning methods. E-learning is described by the writer as 'brain friendly,' and so it is said that "it optimizes learning to the cognitive architecture of the learners. If technology enhanced learning promotes the formation of effective mental representations and works with the human cognitive system, then the learners will not only be able to acquire information more efficiently, but they will also remember it better and use it" (para. $4 \& 5)$.

\section{Operationalization of variables}

Cognitive ability is defined by Subrahmanyam, Kraut, Greenfield, and Gross as "the skills associated with thinking and knowing — the skills required for children to understand language and numbers, to reason and problem solve, and to learn and remember" (2000,pp.127-128).

\section{Types of technologies in school libraries today}

School libraries are gateways to the information-based society in which we live. Therefore, they must provide access to all necessary electronic, computer, and AV equipment (IFLA, p. 9). Quinlan (2012, para. 5) supports IFLA's statement when he refers to Ballard's comment that "libraries have morphed into a hybrid model that pulls resources from the traditional print format and the newer digital format" (para. 5). Rogers, a high school librarian, mentions that her school uses netbooks-small laptops, Kindles-a program that allows students to download a book or periodical onto any device such as an iPad or smartphone, and an educational adaptation of YouTube (Quinlan, 2012, para. 10). She adds that her school library and others use a variety of supplemental academic databases that connect well with different students as well as laptops, Skype, a video chat program that various classes have used to talk to people in other countries, e-books, Nooks, and Kindle readers (Quinlan 2012,para. 7 \& 9).

\section{Technology facilitating cognitive skills}

\section{Students can create knowledge using technologies}

Liu (2003) conducted research with high and elementary school students on the effect of a multimedia environment on students' motivation toward learning and their cognitive skills acquisition. The researchers had students involved in a three-phase project. In phase 1, they 
learned how to use multi-media tools such as software programs; they also got used to the hardware and did exercises related to the hardware. In phase 2, students designed a storyboard and learned multi-media tools. In phase 3, they learned to scan photographs, create animation, and digitize audio.

The findings show that at the high school level, students' understanding was significantly increased for planning, searching information, and connecting ideas (p. 32). At the elementary level, there was a significant increase in students' design knowledge, and they were able to list more relevant concepts than in the pre-concept maps. It was also noted that "needing a storyboard," "leaving more time for revising" and "having a better interface" began to be a part of these students' vocabulary (p. 33).

\section{Technology improves learning}

As Cruse (2006, p. 9) mentioned, that in 1989, Barron conducted two unrelated studies and discovered that the use of video to "anchor" instruction to a shared classroom experience resulted in improved vocabulary use, a greater understanding of plot and characterization, and an increased ability to draw inferences based on historical information (p. 9). Dolegui (2013, para. 5) cited a 1997 study by Cockerton, Moore, and Norman expressing that "although previous research has established that music can either distract or facilitate cognitive task performance, improved performance in the presence of music might be directly related to the type of music listened to." She also referred to the findings of a study conducted by Hallman, Price, and Katsarou in 2002 supporting this argument. These researchers tested the effect of calming and relaxing music on arithmetic and memory performance tests on children ranging from ages 10 to 12. They found better performance on both tasks with calming and relaxing music conditions when compared with no-music conditions.

In the article "Positive effectives of internet usage on child development," the writer articulates that students are exposed to information to improve the quality of learning that can transform into knowledge. The article also mentions that students' language and literacy development is often promoted through the internet, and this allows for greater gains in verbal and nonverbal skills (para. 2).

\section{Retaining of concepts learned}

McDaniel (2014, para. 5) remarks that the interactive SMART Board provides an opportunity for students to interact on a more personal level with the lesson and increases their likelihood of learning and retaining lesson material. It also helps students stay focused by having them use the board as a learning tool that they can interact with using their hands during lesson delivery.

\section{Technology improves capacity to think}

As reported by Nauert (2013,para.7-9), studies have found that video games improve a player's capacity to think about objects in three dimensions, just as well as academic courses targeting these same skills. Nauert explains that this finding has critical implications for education and career development. Jonassen (2010, para. 10) asserts that neither teachers nor technologies are repositories of information and confirms that for students to learn from technology, they (students) should use the technologies around them to represent what they know rather than memorizing what the teacher and the textbook tell them. In other words, students learn best when they use technology to create knowledge. Thus, different technologies should be used as tools to learn with rather than from.

A study done by Sethy (2012, para.29) found that students performed better in content areas, and develop higher order thinking while using technology to learn. Sethy's study (2012) further affirms 
that cognitive skills subsume many activities which include: creativity, judgement, comparison, contradiction, description, interpretation, argument analysis, evaluation, questioning, observation, logical presentation of contents, and problem solving approach. Du Plessis (2008, p. 1) expresses that the most important cognitive skills are concentration, perception, memory, and logical thinking.

\section{Technology engenders dialogue and active learning}

A study conducted by Yiong, Sam, and Wah (2008, p.547) found that students felt they learned better using technology, especially those who facilitated dialogue between peers and teachers. This was because they were able to ask each other, as well as their teachers, questions. The ability to communicate outside of class time allows students to focus more on the quality of learning because they are engaged. Watson and Gable (2010, para. 16) also observed that using technology as a strategy in the learning process can help students with their working memorythe ability to move information from short term to long term memory. This is achieved through the use of interactive software, demonstration, and audio-visual representation of concepts and processes. Working memory is critical to the acquisition of increasingly more complex knowledge and skills.

Mayer (2001, as cited in Cruse, n.d., p. 3) explains that while viewing may appear to be passive, it can involve the high cognitive activity necessary for active learning. Furthermore, he mentions that "well-designed multimedia instructional messages can promote active cognitive processing in students, even when learners seem to be behaviourally inactive. The content and context of the viewing are both crucial elements for engaging students as active learners."

\section{Video games can facilitate the development of cognitive abilities}

Facer (2003, p. 1) cites Greenfield, who argues that the habitual playing of video games results in the development of cognitive abilities that are important in the way we operate in the world.

Klopfer et al. (2009) refer to Jenkins et al. (2006, p. 6) cognitive abilities as:

- The ability to process information very quickly;

- The ability to determine what is and is not of relevance to them;

- The ability to process information in parallel, at the same time, and from a range of different sources;

- Familiarity with exploring information in a non-linear fashion;

- A tendency to access information in the first instance through imagery and then use text to clarify, expand, and explore;

- Familiarity with non-geographically bound networks of communication; and

- A relaxed approach to play - the capacity to experiment with one's surroundings as a form of problem solving.

\section{Technology supports students' learning styles}

Sethy (2012, para.4) cites Askar and Altun (2009), who posit that cognitive skills in a technology enabled teaching-learning situation help learners to access the navigation for their learning path, as cognitive skills facilitate their learning through scaffolding. They continue by suggesting that cognitive skills assist learners in achieving objectives, and cognitive skills enable learners to diagnose their shortcomings related to subject content and use of technological tools, and encourage them to work on their shortcomings.

According to McDaniel (2014, para. 4), students with different learning styles benefit from the use of SMART Board technology. He explains that "because of the size and visual components of the board, students who learn through seeing are better able to process lesson material. Using websites or software on the SMART Board that promotes activities such as learning through 
music is beneficial to audial learners. Students who learn more by touch can use the pen or their fingers to interact with the board as well. Cognitive learners will benefit from the availability of numerous lessons of varying challenge levels available for SMART Boards on the web" (para. 4).

Cruse (2006, p. 10) cites Denning's comment that video may help to promote learning in students with high visual orientation in their learning styles. He continues by stating that the viewing of "videos can also provide visually-compelling access to information for many learners with learning difficulties who might miss learning opportunities provided solely by print-based materials. In this respect, videos provide important learning opportunities to students working in a second language".

\section{Impact of technology on pedagogy}

In this age, teachers are using various technologies and equipment to deliver content to students within and outside of the classroom. These include podcasts of lessons (Pennarola \& Caporarello, 2013), digital gaming (Klopfer et al., 2009), interactive whiteboards (TechLearn), wikis, and blogs (Tucker, 2014, p. 169). These make up part of what Tucker $(2014$, p. 168) refers to as the 'learning ecosystem.' The role of this system is to unite participants "through cooperation, sharing, reflection, publishing, development and learning, and through resources and participants" in an education system that extends beyond the boundaries of the classroom (Tucker, 2014, p. 168).

Okojie, Olinzock, and Okojie-Boulder (2006, para. 5) note that it is important for teachers to recognize that a relationship exists between technology in education and pedagogical decisionmaking. Wong, Li, Choi, and Lee (2008, p. 249) indicate that at present, the ongoing and unprecedented development of technology has led to the widespread use of technology to advance educational goals. School librarians have been trained in the use of technology; therefore, it is evident that they would be a part of those educators who use technology to reshape the delivery of their instruction in order to improve the cognitive skills of the digital generation that they teach.

Wilkin et al. (2013, p. 89) assert that self-efficacy impacts how willing teachers are to try new ways to apply technology in their content delivery. Here, technology is not used as an end but as a strategic lever to deliver content more effectively or engage students in the learning process. Henry-Wilson, a former Jamaican Minister of Education, was quoted as saying that the introduction of technology in pedagogy allows teachers to "segment their classrooms" (Thompson, 2014, para. 15). This allows the teacher to plan a lesson that reaches students with different abilities. Thus, better engagement, creativity, interaction, and classroom management will take place in the class. In Antigua, the article in the "Technology for Communication, Education, and Empowerment",p. 9) stated that by the end of 2011, teachers throughout Antigua and Barbuda would be provided with cutting-edge technology; they would also benefit from technologies that would likely enable them to better plan their lessons as well as establish a variety of databases.

\section{Research objectives are to:}

1. Ascertain the types of technologies currently in school libraries in Jamaica and Antigua;

2. Determine how these technologies facilitated students' cognitive ability in this study;

3. Find out how these technologies modified participants pedagogical practice. 


\section{Methodology}

This is a quantitative study using the survey methodology. One newly developed questionnaire was used to collect data from a select group of school librarians in Jamaica and Antigua. The questionnaire was pilot-tested on two school librarians, adjustments were made, and then it was mailed to each participant with a letter of request for voluntary participation, the assurance of confidentiality, and a return date for the questionnaire. The data was collected over a period of two weeks. The data was then presented, analyzed, conclusion drawn and implicated delineated.

\section{Population}

There are one hundred and forty-eight (148) secondary schools in Jamaica and ten (10) in Antigua, making the population one hundred and fifty-eight (158). These schools had libraries that were equipped with one, two, or more technologies. In addition, other technologies were located in the schools' computer labs and participants had access to them for instruction.

\section{Sample}

The Krejcie and Morgan Table was used to determine the sample size for the population. It indicated one hundred and eight (108) for the Jamaican population and ten (10) for the Antiguan population. However, because of time constraints, simple random sampling was used to select a sample size of seventy (70) school libraries in Jamaica. All ten (10) school libraries in Antigua were selected. The response rate was forty-seven (47) from Jamaica and five (5) from Antigua, making a total of fifty-two (52).

\section{Data collection instruments}

Questions in Section 1 sought demographic data on the participants. In Section 2, data was collected to ascertain the types of technologies in these school libraries. In Section 3, questions sought information on how the technologies in these school libraries facilitated students' cognitive ability, and Section 4 sought data on how these new technologies altered these librarians' pedagogical practice.

\section{Analyses of data}

\section{Demographic data of participants}

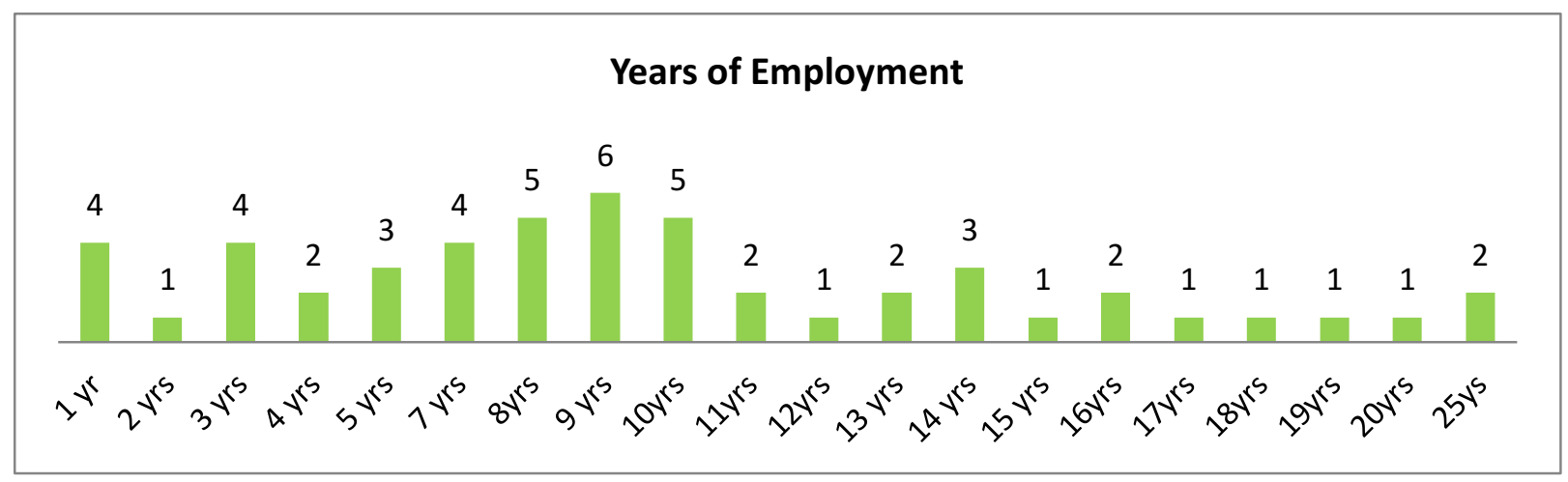

Figure 1: Years of Employment of School Librarians

The data reveals that the majority of school librarians were employed between 1 and 9 years. This seems to suggest that they might not have had experience working in a traditional school library, that is, school libraries without technologies. On the other hand, those who had been working for 
13-25years would have witnessed the gradual change in technological infrastructure in the school libraries. The majority of these school librarians would have been trained in the use of these technologies while they were at library school and would therefore be more likely to use them than those who had been employed for between 15-25 years.

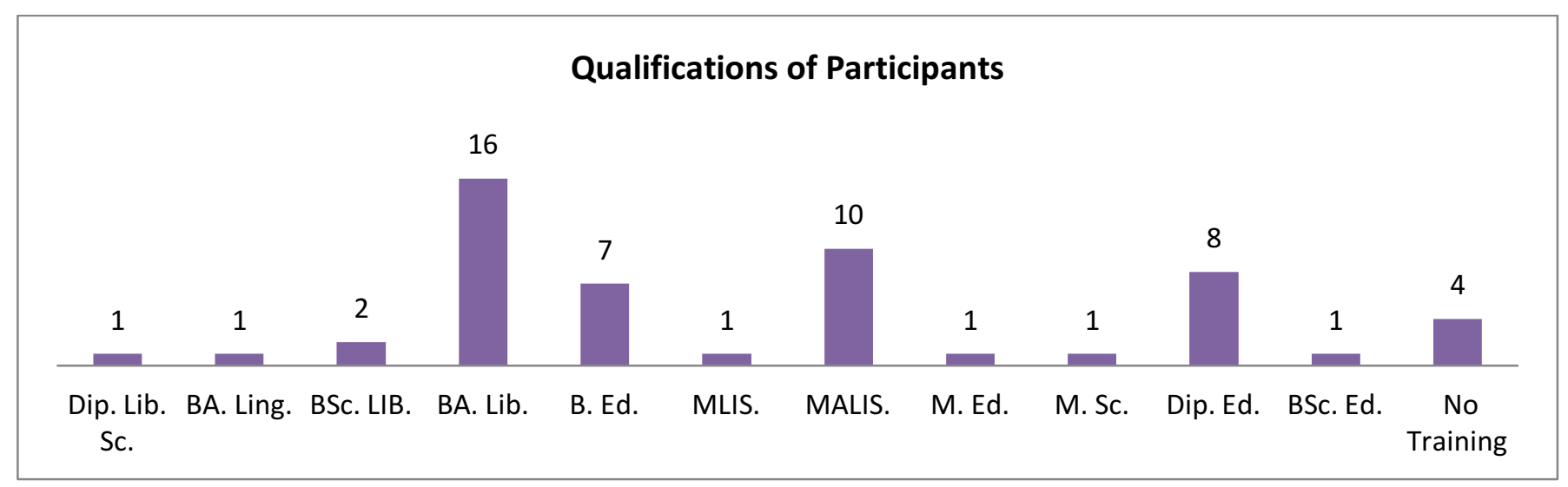

Figure 2:Academic Qualifications of School Librarians

The academic achievements of these participants, as indicated by the data in Figure 2, reveal that the majority of these school librarians were trained in library and information science and would therefore know how to use technologies to deliver information literacy lessons. Those who had other degrees or no training might have learned how to incorporate these in their lessons through professional development workshops/seminars or from their peers.

\section{Wi-Fi in schools}

The data indicated that $88 \%$ of the school had $\mathrm{Wi}-\mathrm{Fi}$, though all had internet access. This electronic infrastructure set the stage for the use of some of the technologies that were found in these libraries. The researchers would like to point out that some of these schools had this service because it was provided to them free of cost from one of the telecommunication technology companies in Jamaica. In Antigua, the "Technology for Communication, Education \& Empowerment" program uses Wi-Fi technology to bring broadband Internet to more than 5,000 secondary school students in their classrooms (Minister of Information, Broadcasting, Communication, Science \& Technology, p. 2).

\section{Bring Your Own Device (BYOD)}

Seventy percent $(71 \%)$ of the participants indicated that students were allowed to take their own devices to school. However, they also indicated that this privilege was given to students in the upper grades, with security issues cited as the reason. In two instances, students had to obtain permission from their parents to bring their own devices to school.

The BYOD initiative had a positive impact on students as they were able to work at their own pace to complete school related tasks. BYOD also enabled students to use technologies while in school when those in the library or computer labs were occupied. 
Table: 1 Types of Technologies School Libraries Access for Teaching

TYPES

Computer with access to the internet

Computer without internet access

Digital camera

Document reader

DVD player

Electronic games

Electronic database

Interactive SMART Board

Laptop

MP3 Player

Multi-media projector

Smart phone

Tablets

\section{NUMBER OF LIBRARIES \\ WITH THESE TYPES OF TECHNOLOGIES}

$\%$ out of 52

51

$98 \%$

14

$26 \%$

35

$67 \%$

18

$18 \%$

35

$67 \%$

8

$14 \%$

8

$14 \%$

24

$47 \%$

35

$48 \%$

5

$10 \%$

53

$100 \%$

4

$7 \%$

7

$14 \%$

Other: Television .19

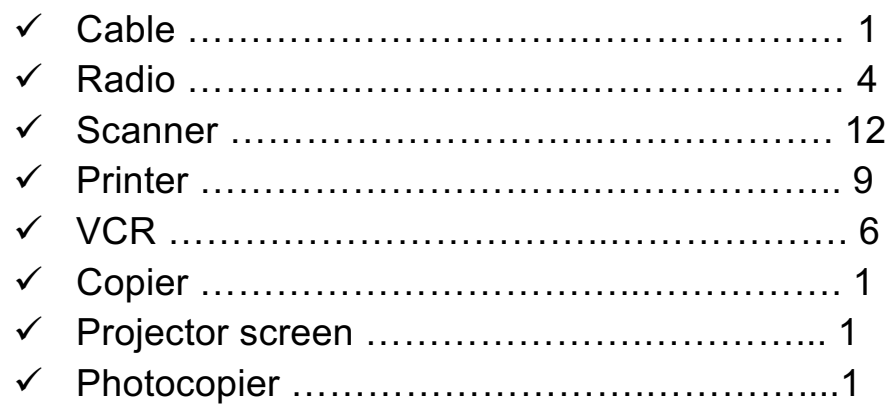

The data in Table 1 reveals that a wide variety of technologies was in these school libraries or was available for use by the librarians. The data shows that all school libraries had a multi-media projector or had access to one. Ninety-six percent (97\%) had computers with internet access, $26 \%$ had computers without internet access, $67 \%$ had digital cameras, $18 \%$ had document readers, $67 \%$ had DVD players, $14 \%$ had electronic games, $14 \%$ had electronic databases, $47 \%$ 
had interactive SMART Boards, 48\% had laptops, 10\% had MP3 players, $100 \%$ had multi-media projectors, $7 \%$ had smartphones, and $14 \%$ had tablets. The data shows that six (6) school libraries still had the traditional VCR.

It is the researchers' knowledge that some of the technologies mentioned, such as computers with and without internet access, multi-media projectors, electronic databases, electronic games, and MP3players, were directly located in these school libraries. However, others such as the interactive SMART Boards, laptops, document readers, and educational DVDs/videos were placed in secondary schools in Jamaica because of the implementation of the e-learning project in these schools. However, the school librarians had access to them for instruction as they were placed in computer labs adjacent to these school libraries and the school librarians were charged with assisting students and teachers in the access and use of the e-learning resources (Pellington, 2012, p. 77). In Antigua, the government continues to explore the use and impact of digital devices in the classroom. Up to 2013,three thousand tablets were distributed to fourth and fifth form students in private and public secondary schools under the Government Assisted Technology Endeavor (GATE) project (Government of Antigua and Barbuda 2013, para. 1, 3).

Impact of these technologies on students' cognitive ability

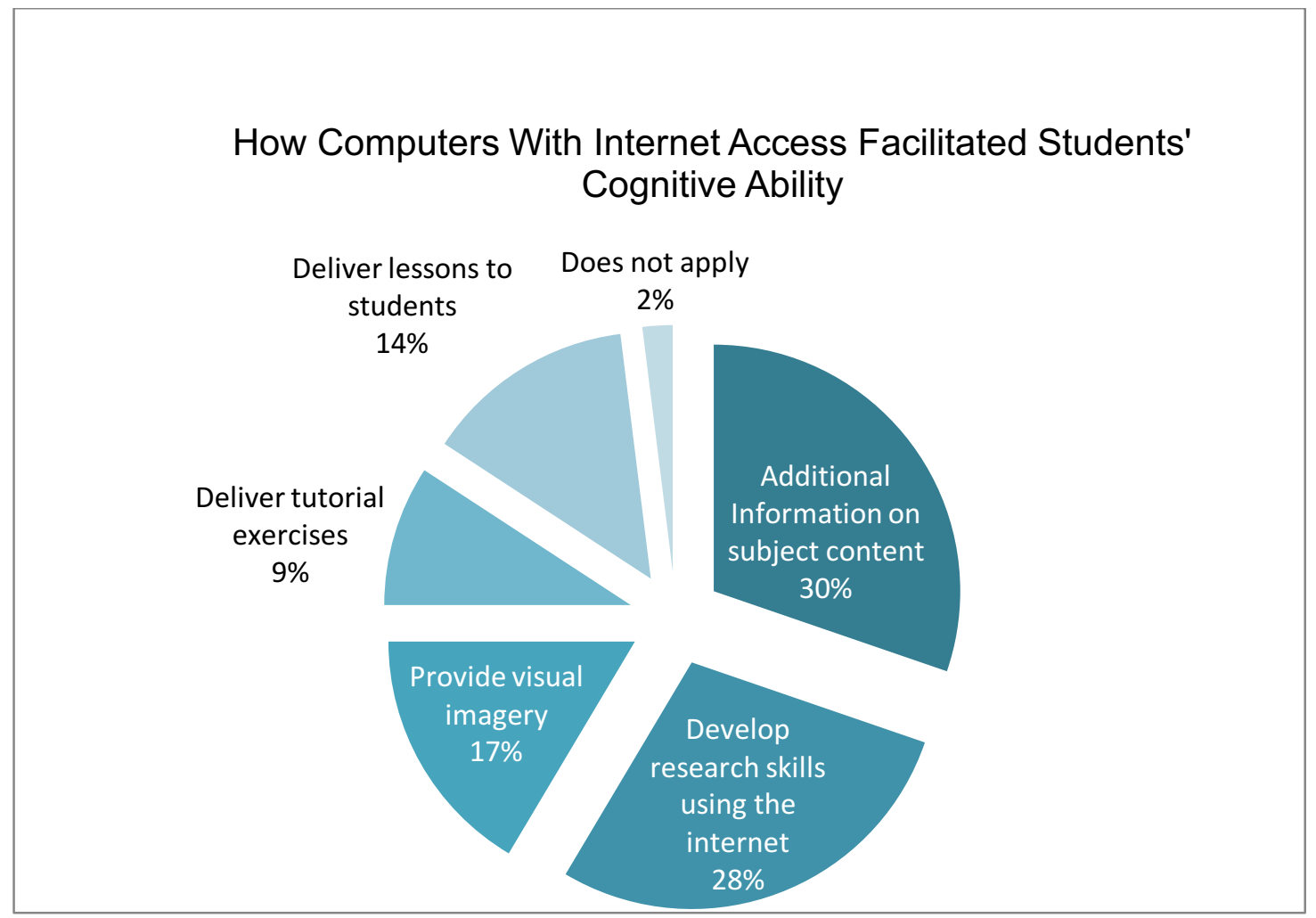

Figure 3: Computers With Internet Access Facilitate Students' Cognitive Ability

The data in Figure 3 indicates that computers with internet access facilitated students' cognitive ability in various ways. Thirty percent $(30 \%)$ of the participants in these islands have indicated that students' academic ability was facilitated by acquiring more information from the internet, while $17 \%$ believed that the visual imagery students saw within the information they garnered facilitated their understanding of the content. Twenty-eight percent $(28 \%)$ indicated that students developed research skills and were able to locate information that improved their cognitive ability. Fourteen 
percent $(14 \%)$ and $9 \%$ of the participants also indicated that the computer with internet access facilitated students' cognitive ability in that they received lessons over the internet as well as tutorial exercises to help them understand difficult concepts.

The writer of the article "Positive effectives of internet usage on child development" supports the finding that students using the internet are exposed to information to improve the quality of their learning, which can be transformed into knowledge. The researchers also believe that the visual imagery facilitates their cognitive ability as it can form a permanent image in students' minds and help them to remember facts. The use of the internet is also attributed to increasing vocabulary, which will assist students in language development and likely lead to the creation of new knowledge.

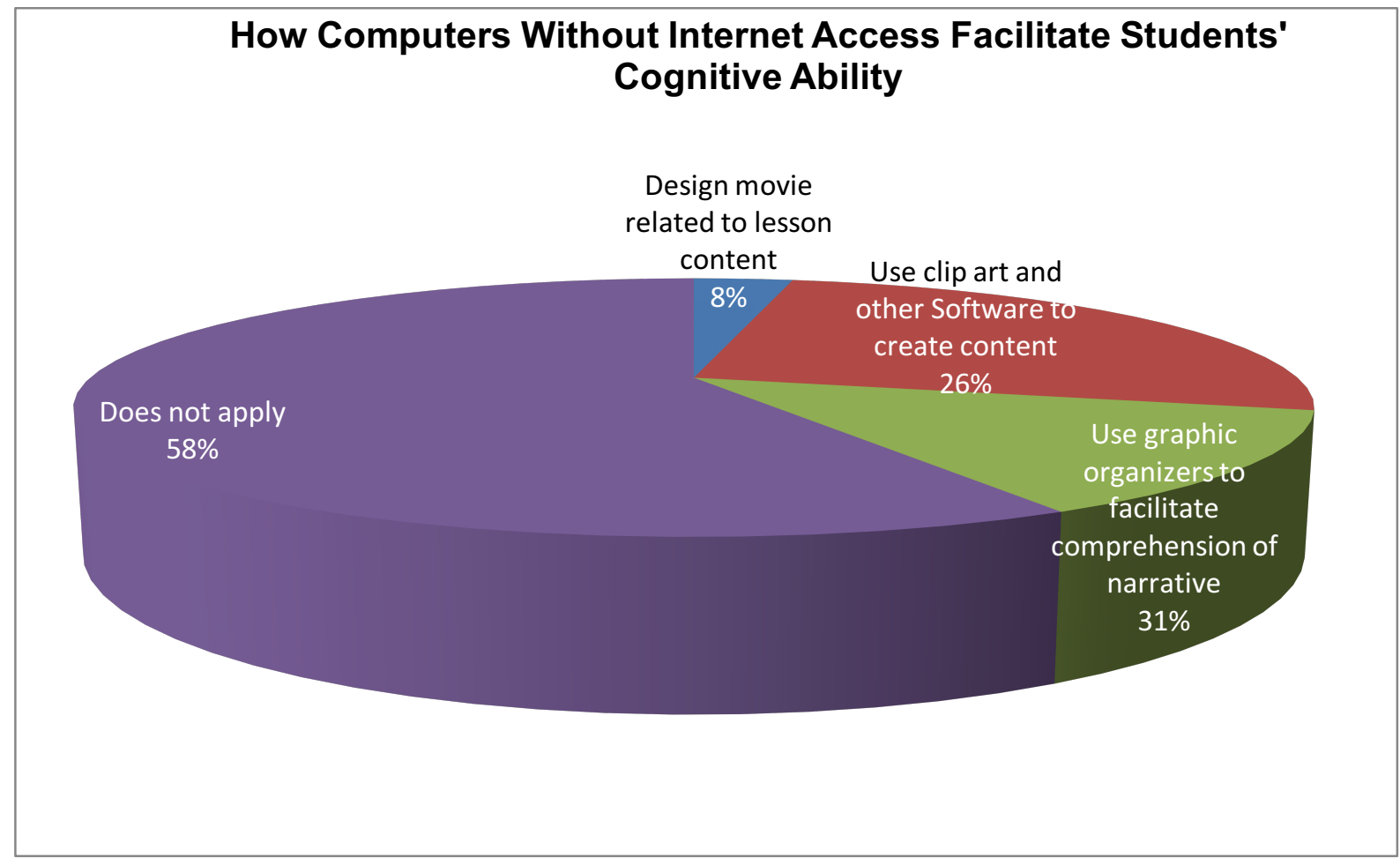

Figure 4: How Computers Without Internet Access Facilitate Students' Cognitive Ability

The data collected in Figure 4 shows that thirteen (13) participants had computers without internet access. These participants indicated that students' use of the graphic organizers facilitated comprehension of narrative. Twenty-six percent $(26 \%)$ indicated that students' cognitive ability was facilitated when they used the clipart software and graphic organizers to assist them in creating content for essays and other assignments. One participant indicated that these software stimulated students' mental capacity to create animation. Eight percent (8\%) of the participants stated that academic performance was increased when they designed movies related to the lessons. Furthermore, Liu's (2003) research findings show that a computer software program can facilitate students' cognitive ability in that student can learn how to scan photographs, use multimedia, and design storyboards. 
The researchers agree that computers without internet access can facilitate cognitive ability when students use software such as PowerPoint and Publisher, which can help them create and publish information learned in a new format.

Table 2. How Electronic Games Facilitated Students' Cognitive Ability

How Electronic Games Facilitate Students' Cognitive Ability

School Libraries' Responses

Reinforce concepts taught

7

Improve slow learners' capacity to think 5

Teach the conceptual knowledge $\quad 2$

Introduce new concepts 3

Assist with the framing of content taught 3

Teach the skill of negotiation 1

Collaborate in order to learn from each other 1

All seven (7) of the school librarians who indicated that they had electronic games in their school libraries specified that these games facilitated students' cognitive ability. Nine percent (9\%) indicated that they increased students' capacity to think, while $5 \%$ noted that they helped students grasp and conceptualize new content.

These findings have some similarity to Facer's (2003) research finding that playing video games helped students to process information quickly and to determine relevant concepts. Nauert's (2013, pp. 7-9) research findings also indicate that playing games improves players' capacity to think about three dimensional objects. Therefore, the impact that these participants have mentioned suggests that students' cognitive ability was improved by getting more opportunities to solve problems and explore information in a non-linear fashion, which, in turn, promoted active cognitive learning. 


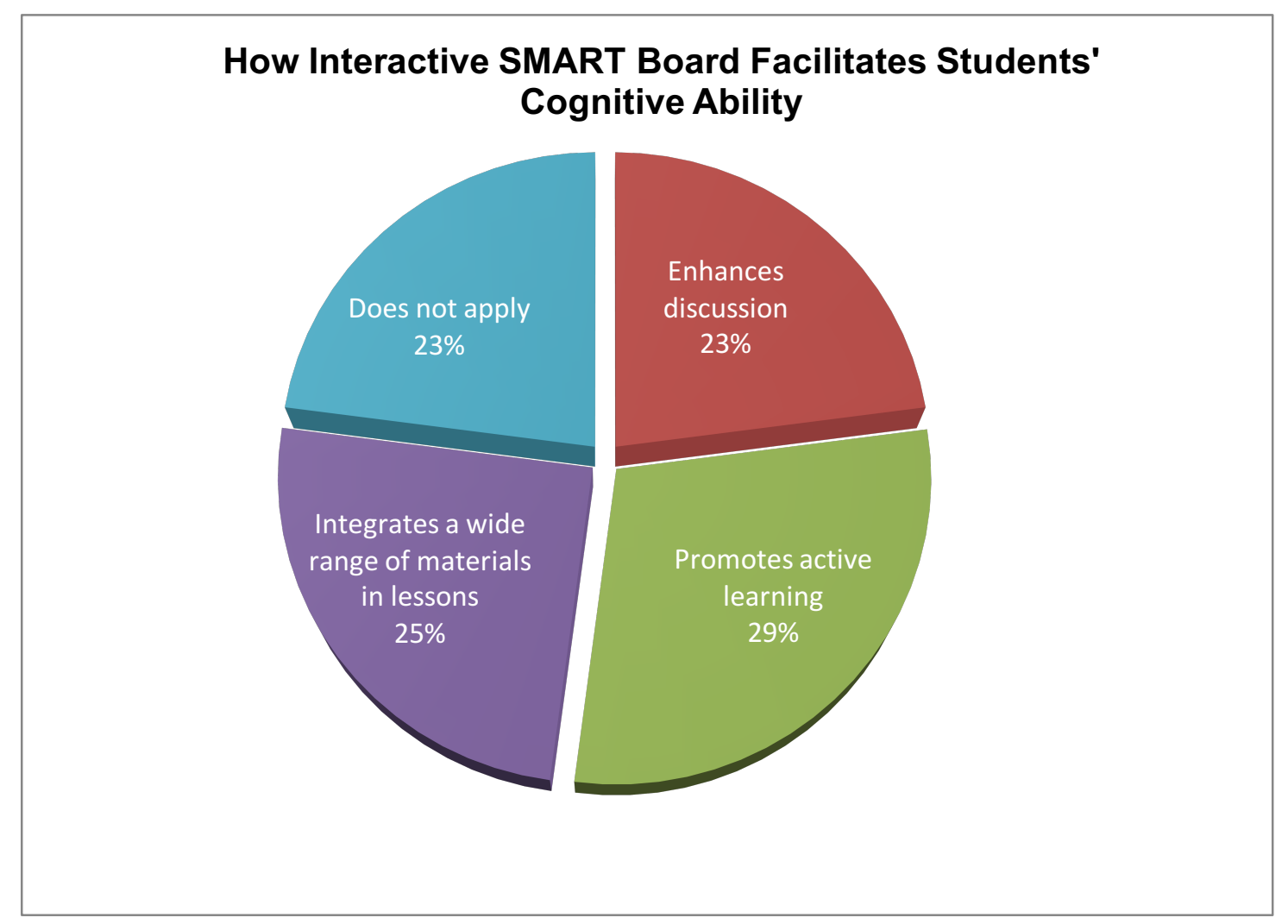

Figure 5:Interactive SMART Board Facilitates Cognitive Learning

Figure 5 shows that of the 24 participants with an interactive SMART Board, twenty-nine percent (29\%) noted that students' cognitive ability was improved because the board promoted active learning, and $25 \%$ pointed out that it positively influenced students' cognitive ability as they used it to integrate a wide range of materials in the their lessons. Another $23 \%$ indicated that when the interactive SMART Board was used, it generated discussions because students were freed from note taking. McDaniel(2014, para. 5) supports these findings as he indicates that the use of interactive SMART Boards provides opportunities for students to interact more with the lesson, which would increase the likelihood of them retaining what they had learned. This interaction can generate discussion among students, during which they are likely to gain knowledge about the lessons being taught.

The researchers are of the opinion that the very nature of the interactive SMART Board influenced active learning, which will keep them alert and focused during instruction, thus improving their cognitive ability. 


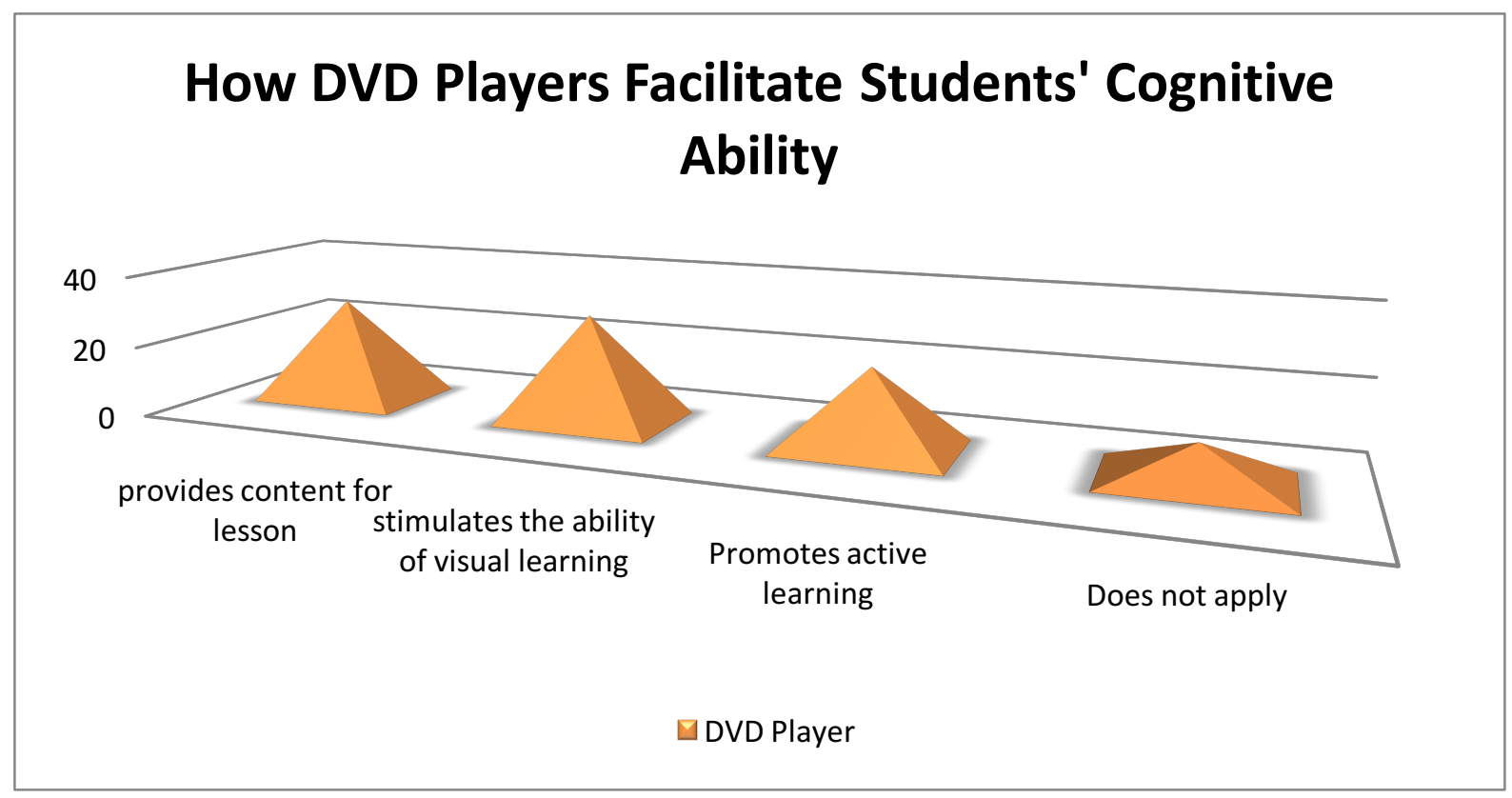

Figure 6: How DVD Players Facilitate Students' Cognitive Ability

The data in Figure 6 shows that twenty-four (24) participants indicated that when students used educational DVDs, their cognitive ability improved as these DVDs provided them with additional multi-media content for their lessons. Twenty-seven percent $(27 \%)$ noted that when their students used DVDs, their visual ability was stimulated. Thirty percent $(30 \%)$ indicated that it promoted active learning.

Cruse's (2006, p. 3) mention of Mayers' comment that the viewing of educational videos can involve the high cognitive activity necessary for active learning is evidence that there are others who support this finding. Cruse (2006) also cites Denning (p. 10) in stating that the viewing of educational videos can provide visually compelling access to information for students with learning difficulties. This finding is further substantiated by the findings from the unrelated studies conducted by Barron (1989), which revealed that the use of video in instruction resulted in improved vocabulary. The researchers believe that based on these findings, the use of educational DVDs did improve these students' cognitive ability. 


\section{How the Tablet Facilitates Students' Cognitive Ability}

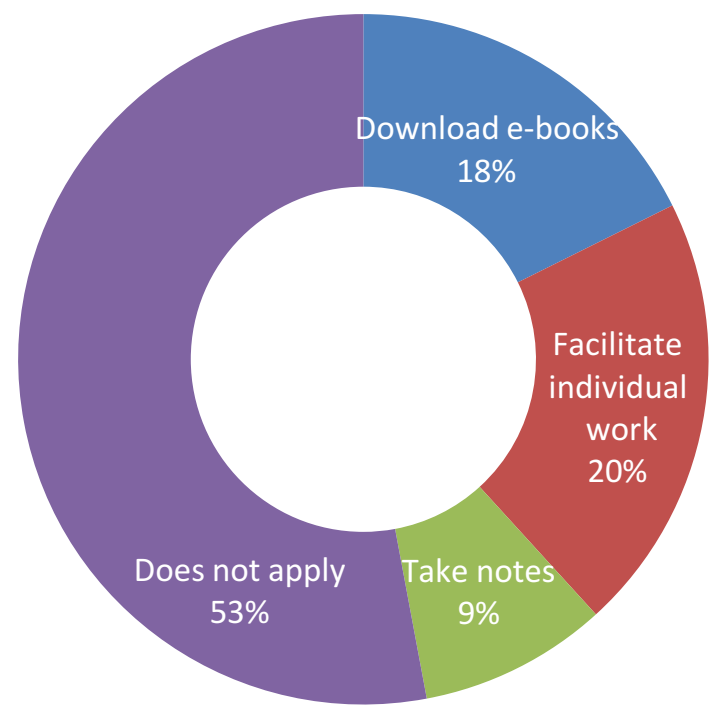

Figure 7: Tablet Facilitates Students' Cognitive Ability

The data in Figure 7 shows that seven (7) of the participants indicated that students had the use of tablets. Twenty percent $(20 \%)$ mentioned that it provided information when students were working individually, $9 \%$ indicated that students used them to take notes, and $18 \%$ used them to download e-books. As was indicated in Table 1, students had access to tablets belonging to their intuitions. In addition, $70 \%$ of the school libraries surveyed allowed students to bring their own devices to school, including tablets.

The researchers are of the opinion that the students' use of tablets helped them to work at their own pace, that they preferred taking notes in this format rather than on paper and were able to garner more information not found in their school libraries. These activities would certainly motivate students as they engaged in the learning process and built their cognitive activity.

The findings show that of the five (5) school libraries that had or provided students with access to MP3 players, 9\% pointed out that they were played while students were completing individual work and stimulated thinking, thus facilitating students' cognitive ability. Dolegui (2013, para. 5) points out Hallman, Price and Katsarou's research findings that students performed better when relaxing music was played during the time students were completing tests.

This strategy is certainly a good one as students of this age group are inclined to listen to music. However, it is the researchers' opinion that these "digital born" students might not appreciate soothing music. Therefore, these librarians might have had challenges when music was introduced initially. It is, however, rewarding that students have been benefitting from this strategy. As Hallman, Price, and Katsarou, in Dolegui (2013), state, "one might imply that this type 
of music can provide a soothing environment that puts students at ease, facilitating cognitive processing" (para. 5).

All school librarians indicated that they used a multi-media projector and that this had facilitated students' cognitive ability by providing visual representation of the content. Eighty-eight percent $(88 \%)$ of the participants indicated that the use of multi-media projectors stimulated students' critical thinking when they viewed content related photographs and YouTube, PowerPoint presentations, etc.

This finding is supported by the results of Sethy's (2012) research showing that students did better in content area and developed higher order thinking when technology was used during instruction. The researchers are confident that since all the participants used multi-media projectors in their instruction, their students were likely to develop critical thinking and the visual representation created a better understanding of the content.

Six participants (6) had electronic databases, which provided students with current journal articles related to the curriculum, and this positively influenced their cognitive ability. The provision of current journal articles would have exposed students to historical and current information that added to these students' knowledge, thus increasing their cognitive ability.

\section{How Technologies Faciliate Students' Preferred Learning Style}
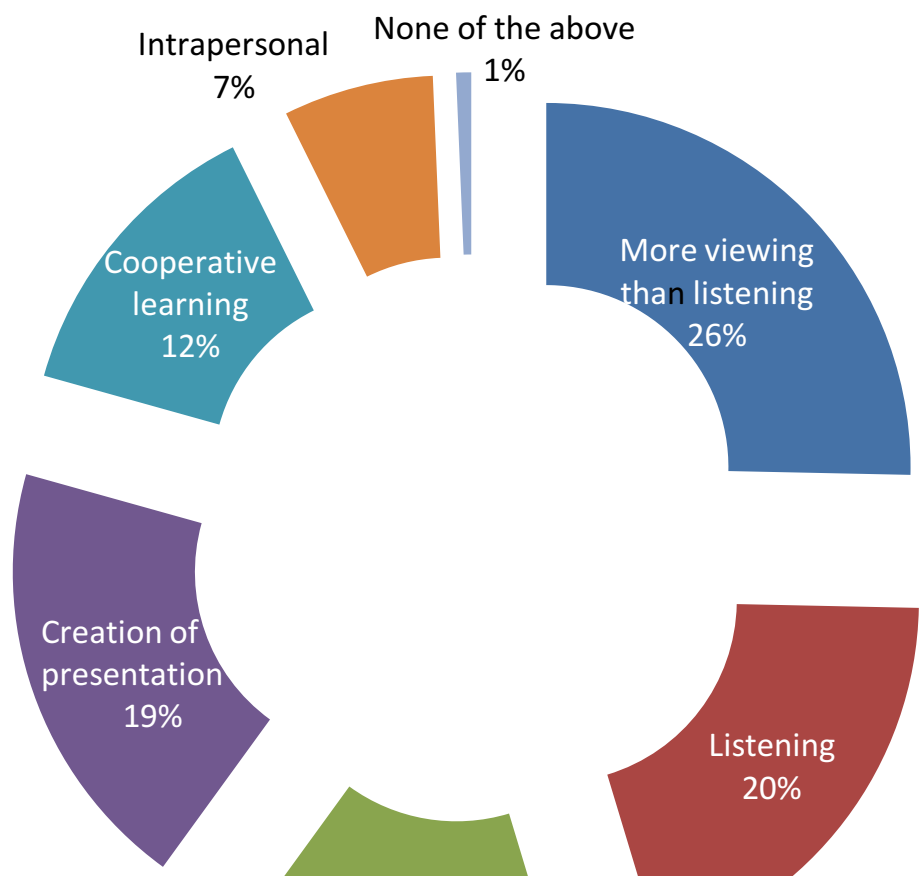

Modelling

$15 \%$

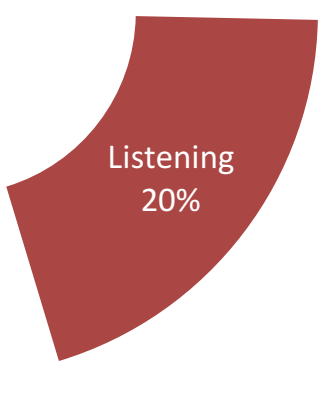

Figure 8: Technologies Facilitate Students' Preferred Learning 
Figure 8 shows $26 \%$ of the participants indicating that students' preferred learning style was catered to because they were allowed to view and listen more than listening only, while $19 \%$ who preferred to listen had the opportunity to do so. Twenty percent (20\%) of the school librarians also indicated that students had the opportunity to create presentations, while $19 \%$ and $15 \%$ indicated that students were able to model the correct examples of content shown. Students whose learning styles were interpersonal and intrapersonal were also accommodated, as is indicated by $9 \%$ and $6 \%$ of the school librarians, respectively. Askar and Altun (2009) also agreed that technology enables students to navigate their learning path. This confirmation suggests that technologies can indeed positively impact students' cognitive ability, and it does not matter which learning style students possess.

\section{Tools Used in the Delivery of Lessons}

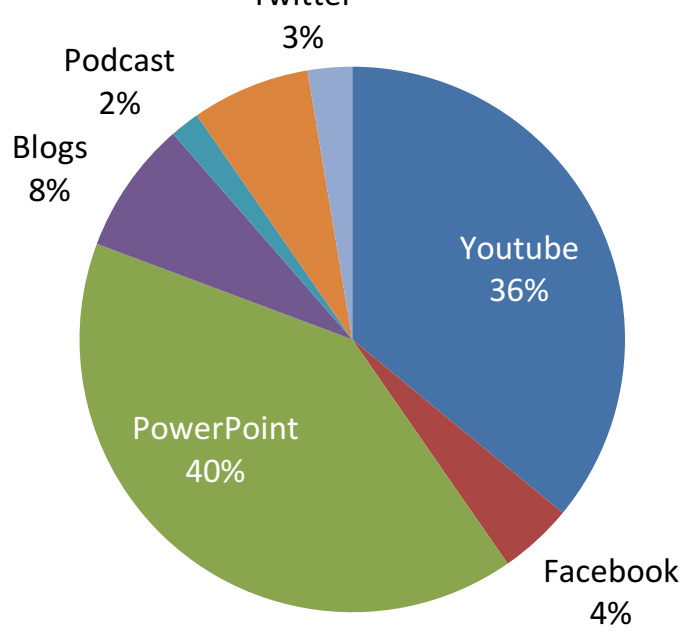

Figure 9: Tools School Librarians used to Deliver Instruction

The data in Figure 9 indicates that $40 \%$ used PowerPoint in their instruction, 36\% used YouTube, $8 \%$ Blogs and $7 \%$ Wiki, $2 \%$ Podcast and $3 \%$ Twitter.

It is obvious that the participants had the use of new technology in their instruction, which involved sight, sound, and color. Some were social media that secondary school students seem to prefer; this may have made them more attentive in class, which means they were likely to learn more. Even though Facebook is a popular Web 2.0 tool, it was not the tool most used by the participants. The researchers deduced that some school administrators are not in favor of having this tool in their institution. Correspondingly, in research conducted by Stewart (2009, p. 19), 20\% of participants indicated that they did not use Facebook because the school policy banned the use of social media in their schools. It would appear that PowerPoint is well-used or even overused. The probable reason is that it is the easiest strategy to use, and if created attractively, it will hold students' attention. It is also possible that participants did not use podcasts, Twitter, and blogs as instructional tools as they were not very proficient at using these tools. 
Table3: New Pedagogical Practices

Electronic delivery of notes

Electronic delivery of assignments to students

Electronic delivery of assignments by students

Use of e-books to supplement print collection

Increased opportunity for communication for students

Use technology as an assessment tool

Provide opportunity for students to collaborate

Retrieve information for lesson plans

Retrieval of content for teaching
YES \% NO \%

53

47

49

51

37

63

27

73

49

51

41

59

71

29

88

12

90

10

Technologies Changes Pedagogical Practice of School Librarians

The data in Table 3 indicates that the participants' pedagogical practice was modified in that $53 \%$ began delivering notes to students electronically, $49 \%$ delivered assignments electronically, $37 \%$ had students delivering assignments electronically to them, $27 \%$ used e-books to supplement print collection, $49 \%$ indicated that there was more communication with students, $41 \%$ used technology as an assessment tool, $71 \%$ indicated that using the technology provided greater participation among students, $88 \%$ used it to retrieve content for their lesson plans, and $90 \%$ retrieved content for teaching.

The data revealed that these participants' pedagogical practice was modified in that they used the various technologies to deliver instruction or to prepare their lessons. This impact seems to have made certain aspects of their teaching-for example, delivering notes and assignments to students and exposing them to e-books-come in line with current practices in other parts of the world. This approach will allow students to become familiar with these teaching strategies before they transition to institutions of higher learning where these pedagogical practices are the norm.

The pedagogical practices that call for collaboration among students are ideal as interaction among students can generate valuable discussions from which both teacher and students can learn. It will also improve the social interaction among students which will help them in the world of work.

The retrieval of information for lesson plans and content for teaching will provide these participants with current teaching strategies and ensure that both students and teachers will stay abreast of new knowledge and school librarians of new teaching strategies. It is important to note that because of these technologies, participants had easy access to information.

\section{Conclusion}

Based on the findings, it can be concluded that several technological devices and infrastructures were located in school libraries or the computer labs to which librarians had access. The findings also show that technologies in these school libraries facilitated students' cognitive ability by way of catering to students' preferred learning styles, facilitating out of classroom communication 
between students and teachers, and among students, and facilitating the research and creation of knowledge. Technology also facilitated modification in the pedagogical practices of teachers by providing tools that they can use to cater to the differing learning styles in their classrooms. Technology has also given school librarians several ways to collect up-to-date content for lessons. The use of technology as a tool thus facilitated participants' efforts to develop students' cognitive ability.

It is important to note that the concept of BYOD already exists in the schools of these countries, even though it is restricted to the upper school. It is hoped that the findings of this study will form the framework for this concept to be fully embraced in all schools in the Caribbean. As the proliferation of technology in Jamaica and Antigua is beyond the budgets of schools and their libraries, this BYOD thrust may free school administrators to fund the acquisition of more software than hardware in addition to other larger devices that will facilitate school librarians' efforts to provide instruction using modern technology in this information age.

\section{Implications}

The study implies that an educational policy should be put in place to ensure that the use of technology is a part of all lessons, as the benefits to the cognitive abilities of students have been proven by many studies, including the current one. In addition, library school education in the Caribbean must continue to put an emphasis on the knowledge and use of these technologies and must incorporate newer ones into its curriculum as they are developed; in this way, it can adequately train new information professionals as well as provide continuing education for those school librarians in service. The use of internet related technology ensures that there is a framework for students to acquire lesson content if they are unable to attend class for reasons such as illness or extra-curricular activities.

The findings also indicate that there was a heavy reliance on PowerPoint and YouTube for the presentation of content by the school libraries surveyed. However, social media such as wikis, blogs, and podcasts were used sparingly. As a result of the impact that YouTube has had in classrooms, it would be prudent of the school librarians to incorporate other web 2.0 tools in view of further facilitating students' cognitive development and modifying pedagogical practices. The study also indicated that nearly one third (29\%) of the persons appointed to the post of school librarian by school boards are untrained. This implies that the skills of librarianship had to be gained on the job and through workshops and by any other means necessary for them to effectively accomplish assigned tasks. The results of the study also indicated that $71 \%$ of those surveyed are trained, ranging from a diploma in librarianship to a Master of Arts in the field. This suggests that the importance of training in the field is increasing within these two countries.

\section{Recommendations}

Based on the findings of the research the following recommendations are suggested:

- To accompany this traditional change, school librarians need to be more engaged in the use of web 2.0 tools such as blogs, wikis, podcast and Twitter. These tools will foster greater student collaboration and cognitive development in non-traditional ways.

- There is room for improvement with regard to certification of school librarians in these two countries; thus workshops are needed to empower these persons to carry out their tasks as effectively as possible until all are properly trained.

- Minimum qualification standards for the appointment of school librarian must be established within these countries.

- A study should be conducted using other countries within the Caribbean to get a more regional understanding of how technology is facilitating students' cognitive ability and changing the pedagogical practices of school librarians in the region. 


\section{References}

Askar, P.,\& Altun, A. (2009). CogSkillnet: An ontology-based representation of cognitive skills. Educational Technology \&Society, 12(2), 240-253. Retrieved April 4, 2014 from http://www.ifets.info/journals/12_2/17.pdf

Bonanno, K. (2012). School libraries supporting 21c learning.Retrieved March 4, 2014 from http://www.schoollibrarymanagement.com/school-libraries-supporting-21c-learning/

Cognitive Consultants International Limited. (n.d.). Retrieved April 6, 2014 from http://www.ccihq.com/index.php?sitelD=4

Cruse. E. (2006). Using educational video in the classroom. Retrieved May 10, 2014 from http://www.safarimontage.com/pdfs/training/usingeducationalvideointheclassroom.pdf

Dolegui, A. S. (2013). The impact of listening to music on cognitive performance. Retrieved May 21, 2014 from http://www.studentpulse.com/articles/762/the-impact-of-listening-to-musicon-cognitive-performance

Du Plessis, S.(2008). Cognitive skills determine learning ability. Retrieved March 12, 2014 from http://ezinearticles.com/?Cognitive-Skills-Determine-Learning-Ability\&id=1318573

Facer, K.(2003). Computer games and learning: Why do we think it's worth talking about computer games and learning in the same breath? Retrieved March 12, 2014 from http://www2.futurelab.org.uk/resources/documents/discussion papers/Computer Games and Learning discpaper.pdf

Government of Antigua and Barbuda. (2013)Thousands of tablets distributed to secondary school students. Retrieved May 23, 2014 from http://www.ab.gov.ag/article details.php?id=4563\&category $=38$

IFLA UNESCO (2002). School library guidelines. Retrieved May 19, 2014. http://www.ifla.org/files/assets/school-libraries-resource-centers/publications/schoollibrary-guidelines/school-library-guidelines.pdf.

Klopfer, E., Osterweil, S., Groff, J., \& Haas, J. (2009). Using the technology of today, in the classroom today: The instructional power of digital games social networking simulations and how teachers can leverage them. Massachusetts: The Education Arcade. Retrieved March 12, 2014 from http://education.mit.edu/papers/GamesSimsSocNets_EdArcade.pdf

Liu, M. (2003). Enhancing learners' cognitive skills through multimedia design. Interactive Learning Environment, 11(1), 23-39. 
McDaniel, R. (2014). How can a smart board be beneficial to students' learning? Retrieved May 21, 2012 from http://www.ehow.com/about_6635274_can-board-beneficial-students_learning_.html

Minister of Information, Broadcasting, Communication, Science \& Technology. (2011).

Technology for communication, education and empowerment .Retrieved May 23, 2014 from http://ab.gov.ag/pdf/telecom_for_com_booklet_hq.pdf

Nauert, N. (2013). Video games can help boost social, memory \& cognitive skills. Retrieved on Feb. 19, 2014 from http://psychcentral.com/news/2013/11/26/video-gameshelp-boost-social-memory-cognitive-skills/62537.html

Okojie, M., Olinzock, A., \& Okojie-Boulder, T. (2006). The pedagogy of technology integration. Journal of Technology Studies, XXX111(2). Retrieved May 2, 2014 from http://scholar.lib.vt.edu/ejournals/JOTS/v32/v32n2/okojie.html

Pennarola, F. \& L. Caporarello (2013). Enhanced class replay, in Charles Wankel, Patrick Blessinger (ed.) Increasing student engagement and retention using classroom technologies: Classroom response systems and mediated discourse technologies (Cutting-edge Technologies in Higher Education, Volume 6), 143-162.

Pellington, B. (2012). The role of the school library in the Jamaican e-learning project: A survey of teachers and students. Mona, Jamaica: University of the West Indies. Diss.

Peltier-Davis, C.,\&Rennick, S. (2007). School libraries in the Caribbean: A Jamaican case study, in Caribbean libraries in the $21^{\text {st }}$ century, changes, challenges and choices. New Jersey: Information Today.

Quinlan, M. (2012). Libraries in schools keeping up with times. Retrieved April 8, 2014 from http://www.boston.com/news/local/articles/2012/04/01/high_sc hool_libraries_more_than_just_a_place_to_study_these_days_1333162611/

Stewart, P. (2009). Web 2.0: Knowledge and use by a select group of teacher-librarians. Proceedings of the 38th International Association of School Librarianship Conference 2009 at the Alexander Palace Hotel, Padova, Italy.

Sethy, S. (2012). Cognitive skills: A modest way of learning through technology. Turkish Online Journal of Distance Education, 13(3): Article 19. Retrieved March 12, 2014 from. http://tojde.anadolu.edu.tr/tojde48/articles/article_19.htm

Subrahmanyam, K., Kraut, K. Greenfield M. \& Gross, F. (2000). The impact of home computer use on children's activities and development. Children and Computer Technology, 10(2), 123-144.

The e-learning Jamaica project(n.d.). Retrieved April 4, 2014 from http://www.mmt.gov.jm/PDF\%20Files/E-Learning\%20Project/The_eLearning_project_Information_Sheet.pdf

Thompson, K.(February 13, 2014). Managers of e-Learning project tout positive results. The Jamaica Observer. Retrieved March 12, 2014 from 
http://www.jamaicaobserver.com/news/Managers-of-e-learning-project-tout-positiveresults_16006381

Tucker, S. Y. (2014). Transforming pedagogies: Integrating $21^{\text {st }}$ century skills and web 2.0 technology. Turkish Online Journal of Distance Education,15(1), 166 - 172.

Watson, S. M. R., \&Gable, R.A. (n.d.). Using knowledge of student cognition to differentiate instruction. Reaching every learner: Differentiating instruction in theory and practice. Retrieved March 12, 2014 fromhttp://www.learnnc.org/lp/editions/every-learner/6693

Wilkin, C.L. et al. (2013). Where technologies collide: A technology integration model. Increasing student engagement and retention using classroom technologies: Classroom response systems and mediated discourse technologies. Cutting-edge Technologies in Higher Education, 6, 81-106.

Yiong, B. L.C., Sam, H. K.,\& Wah, T. K. (2008). Acceptance of e-learning among distance learners: A Malaysian prospective. ASCLITE 2008 Melbourne. Retrieved April 23, 2014 from http://www.ascilite.org.au/conferences/melbourne08/procs/lim.pdf

Paulette Stewart is a lecturer in the Department of Library Studies at the University of the West Indies, at Mona. She is the IASL Regional Director for Latin America and the Caribbean and was the President of the Library and Information Association of Jamaica (LIAJA) in 2010.

Dr. Stewart received the Ken Haycock Leadership Award in 2006 in Portugal for her outstanding leadership role in the Schools Section of the Library and Information Association of Jamaica. She was also elected by LIAJA as Librarian of the year in 2009. Her research interests include, school library education, school libraries and information literacy.

Kerry-Ann Rodney-Wellington is an assistant lecturer in the Department of library and Information Studies, The University of the West Indies, Mona. Kerry-Ann is a member of the IASL Library Education Leadership Team. She is a teacher and a librarian interested in the practice of information literacy. 